\title{
CORAK DAN METODOLOGI TAFSIR ALQURAN AL-MADJID AN-NUR KARYA HASBI ASH-SHIDDIEQY
}

\author{
M. Abdurrahman Wahid
}

Mahasiswa Pascasarjana UIN Sunan Kalijaga Yogyakarta

Abstract:

The interpretation of the Qur'an has begun since the Holy Qur'an was delivered by the prophet Muhammad SAW to his people, this is a historical reality that cannot be denied by anyone including western and eastern historians, both Muslim and non-Muslim. Then the interpretation of the Qur'an in Indonesia is an effort made to explain the contents of the Qur'an to the Indonesian people through the language used by the nation. In the study of the interpretation of the Qur'an in Indonesia's early period, the interpretation of the Qur'an in Indonesian was marked by the emergence of several translations and interpretations of juz uz amma. The interpretations that existed at that time were still partial and not yet a complete interpretation. Until later in the late 60's, Hamka began writing an interpretation which was later called the interpretation of al-Azhar. Besides that Hasbi ashShiddieqy also compiled an interpretation entitled al-Qur'an al-Madjid in several volumes and then gathered it into anNur's interpretation and refined it into al-Bayan's interpretation. This paper will try to discuss the interpretation of an-Nur by Hasbi ash-Shiddieqy. The method used in the interpretation is the method of tahlili (analytical) and muqaran (comparative) while the interpretation style is the interpretation of al-Adabī wa al-Ijtimā'iy. An-Nur's interpretation is one of the major influential works in Indonesia, it is evident that this interpretation book is a reference for PTAIN in Indonesia, both in the Faculty of Islamic Education and in the Faculty of Sharia. 
Penafsiran Alquran telah dimulai sejak kitab suci Alquran disampaikan oleh nabi Muhammad Saw. kepada umatnya, hal ini merupakan kenyataan sejarah yang tidak dapat dibantah oleh siapapun termasuk oleh sejarawan barat maupun timur, baik muslim maupun non muslim. Kemudian tafsir Alquran di Indonesia merupakan sebuah upaya yang dilakukan untuk menjelaskan isi kandungan Alquran kepada bangsa Indonesia melalui bahasa yang digunakan oleh bangsa tersebut. Dalam kajian tafsir Alquran di Indonesia periode awal, penafsiran Alquran berbahasa Indonesia ditandai dengan munculnya beberapa terjemahan dan tafsiran juz 'amma. Karya-karya tafsir yang ada pada saat itu masih bersifat parsial dan belum merupakan penafsiran yang utuh. Sampai kemudian pada akhir tahun 60-an, Hamka mulai menulis sebuah tafsir yang kemudian disebut tafsir al-Azhar. Di samping itu Hasbi ashShiddieqy juga menyusun sebuah tafsir yang berjudul Alquran al-Madjid dalam beberapa jilid dan kemudian dikumpulkan menjadi tafsir an-Nur dan disempurnakan menjadi tafsir al-Bayan. Tulisan ini akan berusaha membahas tentang tafsir an-Nur karya Hasbi ash-Shiddieqy. Metode yang digunakan dalam tafsirnya adalah metode tahlili (analitis) dan muqaran (komparatif) sedangkan corak tafsirnya adalah tafsir al-Adabi wa al-Ijtima'iy. Tafsir an-Nur ini merupakan salah satu karya besar yang berpengaruh di Indonesia, hal ini terbukti bahwa kitab tafsir ini menjadi rujukan PTAIN di Indonesia, baik di Fakultas Ushuluddin maupun di Fakultas Syariah.

\section{Kata kunci: Tafsir, Alquran al-Madjid an-Nur, Hasbi ash-Shiddieqy PENDAHULUAN}

Hasbi ash-Shiddieqy (1904-1975 M) seorang ulama Indonesia, ahli ilmu fiqh dan ushul fiqh, tafsir, hadis, dan ilmu kalam. Dua karya besarnya dalam bidang tafsir yaitu kitab tafsir Alquran al-Madjid an-Nur dan kitab tafsir al-Bayan menjadi rujukan dan inspirasi bagi para ulama Indonesia untuk menafsirkan 
Alquran menggunakan bahasa Indonesia, dimana pada waktu itu para ulama masih bersitegang tentang boleh tidaknya menerjemahkan sekaligus menulis Alquran dengan bahasa diluar bahasa induk, yaitu bahasa Arab. Salah satu ulama yang melarang adalah Ibnu Taimiyah, pendapatnya dalam Iqtida al-Sirat alMustaqim yang dikutip Rasyid Ridha dalam tafsir al-Manar, alasan dibalik ketidakbolehan ini adalah tidak mungkin bahasa Alquran dapat disalin ke dalam bahasa lain dengan makna yang tepat sekaligus memadahi. ${ }^{1}$

Sedangkan ulama yang membolehkan diantaranya adalah alSyatibi, sementara Hasbi sendiri sependapat dengan al-Syatibi. Bagi Hasbi, Alquran sendiri di banyak tempat menyebut identitas dirinya sebagai peringatan bagi seluruh alam (dikr li al-'alamin). Bahkan Nabi Muhammad diutus untuk menjadi pengingat seluruh manusia (nazir li al-'alamin), karenanya agar Alquran dapat mengfungsikan dirinya menjadi dikr li al-'alamin, maka penggunaan yang dipakai oleh setiap bangsa merupakan salah satu cara untuk menunjang tercapainya fungsi Alquran tersebut. Tidak terkecuali menggunakan bahasa Indonesia adalah salah satu cara efektif untuk terlibat aktif menuntaskan misi Alquran tersebut. ${ }^{2}$

Atas karya tafsir yang telah dihasilkan, Hasbi dapat dikategorikan sebagai salah satu pelopor tafsir di Indonesia, bersama Hamka, Ahmad Hasan, Mahmud Yunus, dan para tokoh lainnya. Merekalah yang berusaha melakukan upaya penafsiran Alquran, sementara ulama lain masih menganggapnya tabu bahkan haram. ${ }^{3}$ Itulah sebabnya tulisan berikut ini ingin menyajikan sosok Hasbi ash-Shiddiqiey dengan segala kelebihan dan kekurangannya

\footnotetext{
${ }^{1}$ Nourouzzaman Shiddiqi, Fiqh Indonesia: Penggagas dan Gagasannya (Yogyakarta: Pustaka Pelajar, 1997), h. 107.

${ }^{2}$ Nourouzzaman Shiddiqi, Fiqh Indonesia, h. 107.

${ }^{3}$ Munirul Abidin, Paradigma Tafsir Perempuan di Indonesia (Malang:

UIN Maliki Press, 2011), h. 61.
} 
melalui karya monumentalnya tafsir Alquran al-Madjid an-Nur, sebagai salah satu upaya untuk mengenalkan lebih dekat terhadap tafsir Alquran di Indonesia.

\section{SETTING HISTORIS - BIOGRAFIS HASBI ASH-SHIDDIQIEY}

\section{Latar Belakang Pendidikan}

Hasbi Ash-Shiddieqy dilahirkan di Aceh Utara lebih tepatnya di Lhokseumawe pada tanggal 10 Maret 1904. Beliau merupakan keturunan keluarga ulama dan umara. ${ }^{4}$ Ibunya Tengku ${ }^{5}$ Amrah, merupakan anak dari Tengku Abdul Aziz, yang menjabat sebagai Qadli Chik Maharaja Mangkubumi. Hasbi juga keponakan Abdul Jalil, bergelar Tengku Chik di Awe Geutah, seorang ulama sekaligus pejuang yang bersama Tengku Tapa bertempur di Aceh melawan Belanda. Tengku Chik di Awe Geutah, oleh masyarakat Aceh Utara dianggap sebagai seorang wali yang dikeramatkan. Kuburannya masih diziarahi untuk meminta berkah ${ }^{6}$. Pamannya yang lain bernama Teungku Tulot, menjabat Raja Imeum di awal pemerintahan Sri Maharaja Mangkubumi. ${ }^{7}$

${ }^{4}$ Saiful Amin Ghofur, Profil Para Mufasir Al-Qur'an (Yogyakarta: Pustaka Insan Madani, 2008), h. 202.

${ }^{5}$ Di Aceh Utara dan Timur, gelar Tengku dipakai juga oleh Uleebalang. Lihat Teuku Ibrahim Alfian, "Perang di Jalan Allah," Disertasi (Yogyakarta: Universitas Gajah Mada, 1981), p. 40. Dalam Nourouzzaman Shiddiqi, Fiqh Indonesia Penggagas dan Gagasannya, (Yogyakarta: Pustaka Pelajar, 1997), h. 244.

${ }^{6}$ Banyak cerita yang tersebar untuk mendukung kekeramatan Tengku di Awe Geutah, antara lain: ia selalu bershalat Jum'at di Masjidil Haram. Jika orang Arab menginginkan buah durian ia dapat memenuhinya dengan mencucukkan potong ranting kering di padang pasir yang gersang, kemudian segera akan muncul sepohon durian berbuah lebat dan ranum. Orang yang berniat buruk terhadap dirinya akan mengalami kesulitan, dan baru berakhir sampai orang tersebut datang mengaku dan meminta maaf dan dimaafkan. Lihat Fiqh Indonesia..., h. 244.

${ }^{7}$ Nourouzzaman Shiddiqi, Fiqh, h. 3. 
Pada saat berusia delapan tahun Hasbi telah khatam mengaji Alquran. Satu tahun berikutnya Hasbi belajar ilmu qiro'ah dan tajwid serta belajar dasar-dasar ilmu tafsir dan fikih kepada ayahnya. Permintaan Kontrolir Lhokseumawe kepada ayah Hasbi agar ia di masukkan ke sekolah gubernemen ${ }^{8}$ ditolaknya, karena khawatir anaknya akan dipengaruhi pikiran serani (Nasrani). Sang ayah ingin agar anaknya kelak menjadi seorang ulama. Oleh karenanya Hasbi diantarkan belajar ke dayah (pesantren). Ada dua alasan mengapa Hasbi belajar di dayah. Pertama, meneruskan tradisi leluhur. Kedua, keinginan ayahnya menjadikan Hasbi seorang ulama. Karena kedudukan dan penghargaan terhadap ulama sangat tinggi di mata mastarakat Aceh.

Setelah pengetahuan dasar dirasa cukup, kemudian pada tahun 1916 Hasbi pergi merantau atau mondok ke dayah Teungku Chik di Tanjungan Barat yang bernama Idris, di Samalanga selama dua tahun. Dayah ini salah satu dayah terbesar dan terkemuka di Aceh Utara. Disini khusus mengkaji ilmu fikih. Setelah itu Hasbi pindah ke dayah Teungku Chik di Kruengkale di Aceh Rayeuk, yang bernama Hasan. Hasbi belajar hadis, dan memperdalam fikih selama dua tahun. Tahun 1920 Hasbi mendapat syahadah dari

${ }^{8}$ Sejak tahun 1907, Van Daalen, Gubernur Aceh, memprakarsai didirikan sekolah-sekolah gubernemen di Aceh. Sekolah pertama dibuka di Kutaraja dengan murid tiga puluh delapan orang. Pada tanggal 1 Mei 1910, dibuka sekolah putri di Ule Lheu. Pada tahun 1909 sudah lima puluh satu buah sekolahan didirikan. Sepuluh tahun kemudian, meningkat menjadi 258 buah dengan jumlah murid 15.476 orang. Dua puluh diantaranya sekolah putri dengan jumlah murid 1.161 orang. Lihat Kreemer, Atjeh II, 159, 165; lihat juga Ibrahim Alfian, "Sebuah Studi", p. 122. Tujuan Pemerintah Kolonial Hindia Belanda mendirikan sekolah putri adalah untuk mencegah kaum perempuan Aceh berperan serta dalam perlawanan bersenjata terhadap belanda, lihat, C.L.,"School in Huwelijk op Atjeh" dalam Tijdschrift Voor Binnelandsche Bestuur (1915) IV: 307-9. Seperti yang dikutip Ibrahim Alfian, "Sebuah Studi", p. 123. Dalam Nourouzzaman Shiddiqi, Fiqh Indonesia Penggagas dan Gagasannya, h. 246. 
Teungku Chik Hasan Kruengkale sebagai pernyataan bahwa ilmunya telah cukup dan berhak membuka dayah sendiri. ${ }^{9}$

Setelah menyelesaikan studi di dayah Teungku Chik di Kruengkale, beliau bertemu dengan Syaikh Muhammad Ibn Salim al-Kalali yang merupakan salah seorang pembaharu pemikiran Islam di Indonesia, yang bermukim di Lhokseumawe. Dari Syaikh al-Kalali ia dapat membaca kitab-kitab yang ditulis oleh peloporpelopor pembaharu pemikiran Islam. Dia juga bisa membaca majalah-majalah berisi suara pembaharuan, yang diterbitan di Singapura, Pulau Pinang dan Padang. Dengan Syaikh al-Kalali beliau mendiskusikan konsep dan tujuan pembaharuan Islam. ${ }^{10}$

Syaikh al-Kalali melihat ada potensi besar pada diri Hasbi untuk menjadi seorang tokoh pembaharu pemikiran Islam di Aceh, oleh karena itu Syaikh al-Kalali menganjurkan Hasbi untuk pergi ke Surabaya belajar pada perguruan al-Irsyad yang diasuh oleh pergerakan al-Irsyad wal Islah yang didirikan oleh Syaikh Ahmad as-Surkati. Pada tahun 1926 Hasbi diantar Syaikh al-Kalali berangkat ke Surabaya untuk melanjutkan studinya di perguruan al-Irsyad. Sampai disana diuji secara keilmuan, akhirnya Hasbi diterima pada jenjang takhashshush. Pada jenjang ini Hasbi mendalami bidang Bahasa Arab yang merupakan mata pelajaran terpenting dalam kurikulum perguruan al-Irsyad. ${ }^{11}$

Hasbi banyak bergaul dengan orang-orang Arab yang ada di Surabaya. Bahkan beliau mondok di salah satu rumah orang Arab. Hal ini mendukung pendidikan bahasa Arab yang sedang dijalaninya. Hanya satu setengah tahun Hasbi belajar di perguruan al-Isryad beliau memperoleh kemahiran berbahasa Arab. Dan kemapanan berada berada di barisan para pembaharu Islam, untuk

\footnotetext{
${ }^{9}$ Nourouzzaman Shiddiqi, Fiqh Indonesia, h. 13-14.

${ }^{10}$ Nourouzzaman Shiddiqi, Fiqh Indonesia, h. 15.

${ }^{11}$ Nourouzzaman Shiddiqi, Fiqh Indonesia, h. 16.
} 
mengibarkan panji-panji islah serta semangat kebangsaan Indonesia. Yang telah menjadi keinginan Hasbi sejak meudagang pada dayah Teungku Chik di Tanjungan Barat di Samalanga. Di perguruan al-Irsyad pada jenjang pendidikan takhashshush, merupakan pendidikan formal terakhir yang ditempuh Hasbi. Dia tidak pernah belajar ke luar negeri. Tamat dari perguruan Al-Irsyad Hasbi memperkaya keilmuannya dengan belajar sendiri. Berkat minat baca, minat belajar, serta minat menulis yang besar, Hasbi menghasilkan lebih dari seratus judul buku, dan ratusan artikel. Beliau memperoleh dua gelar doktor H.C., satu dari Unisba pada tahun 1975 dan dari IAIN Sunan Kalijaga tahun 1975, dan juga menduduki jabatan fungsional pada tingkat Guru Besar pada tahun $1960 .{ }^{12}$

\section{Karya-Karya Hasbi ash-Shiddiqiey}

Hasbi mulai menulis sejak tahun 1930-an, Karya tulisnya yang pertama adalah sebuah booklet yang berjudul Penoetoep Moeloet. Pada tahun 1933, disamping menduduki jabatan wakil direktur, Ia juga menulis artikel dalam Soeara Atjeh. Tahun 1937, ia memimpin sekaligus penulis semua artikel majalah bulanan alAhkam dan majalah Fiqh Islami, penerbitnya Oesaha Penoentoet di Kutaraja. Pada tahun 1939 Hasbi menjadi penulis tetap pada majalah bulanan Pedoman Islam, yang diterbitkan di Medan. Dalam majalah ini ia mengisi dua rubrik. Dalam menulis rubrik "Ilmoe Moeshthalah Ahli Hadits", hingga sampai penerbitan kedelapan berganti judul menjadi "Sejarah Hadits-Hadits Tasjri", ia menggunakan nama samaran Ibnoel Hoesein. Untuk rubrik "Dewan Tafsir" ia menggunakan nama samaran Aboe Zoeharah. ${ }^{13}$

\footnotetext{
${ }^{12}$ Nourouzzaman Shiddiqi, Fiqh Indonesia, h. 16.

${ }^{13}$ Nourouzzaman Shiddiqi, Fiqh Indonesia, h. 54.
} 
Pada tahun 1940 Hasbi menulis pada majalah Pandji Islam, yang diterbitkan di Medan dan Aliran Moeda yang sejak penerbitan yang keempat berganti nama menjadi Lasjkar Islam diterbitkan di Bandung. Dalam Pandji Islam, ia mengisi rubrik "Iman dan Islam" dan dalam aliran Moeda/Lasjkar Islam ia memelihara rubrik "Pandoe Islam" dengan judul "Moeda Pahlawan Empat Poeloeh". Ia juga menulis artikel-artikel yang dimuat dalam majalah-majalah antara lain: Hikmah, Pandji Masyarakat, Suara Muhammadiyah, Aldjami'ah, dan Sinar Darussalam. ${ }^{14}$

Hasbi merupakan seorang yang produktif dalam menulis, ada 50 artikel sudah ditulisnya. Terdapat 72 judul buku dari 130 jilid yang menjadi karya Hasbi. 72 judul buku itu adalah keseluruhan dari buku tafsir dan ilmu Alquran 6 judul, buku hadis 8 judul, buku fikih 36 judul, buku tauhid/kalam 5 judul, buku umum mengenai Islam 17 judul.

\section{TAFSIR ALQURAN AL-MADJID AN-NUR}

\section{Latar Belakang Penulisan}

Penulisan tafsir ini dilakukan dalam perhelatan tafsir Alquran di mana ulama masih bersitegang tentang boleh tidaknya menerjemahkan sekaligus menulis Alquran dengan bahasa diluar bahasa induknya, yaitu bahasa Arab. Ibnu Taimiyah adalah salah seorang ulama yang melarang keras menggunakan selain bahasa Arab dalam menafsirkan Alquran. Pendapat Ibnu Taimiyah ini tampak jelas dalam Iqtida al-Sirat al-Mustaqim yang dikutip Rasyid Ridha dalam tafsir al-Manar. Alasan di balik ketidakbolehan ini adalah tidak mungkin bahasa Alquran dapat

\footnotetext{
${ }^{14}$ Nourouzzaman Shiddiqi, Fiqh Indonesia, h. 55.
} 
disalin ke dalam bahasa lain dengan makna yang tepat sekaligus memadahi. ${ }^{15}$

Sedangkan ulama yang membolehkan diantaranya adalah alSyatibi, sementara Hasbi sendiri sependapat dengan al-Syatibi. Bagi Hasbi, Alquran sendiri di banyak tempat menyebut identitas dirinya sebagai peringatan bagi seluruh alam (dikr li al-'alamin). Bahkan Nabi Muhammad diutus untuk menjadi pengingat seluruh manusia (nazir li al-'alamin), karenanya agar Alquran dapat mengfungsikan dirinya menjadi dikr li al-'alamin, maka penggunaan yang dipakai oleh setiap bangsa merupakan salah satu cara untuk menunjang tercapainya fungsi Alquran tersebut. Tidak terkecuali menggunakan bahasa Indonesia adalah salah satu cara efektif untuk terlibat aktif menuntaskan misi Alquran tersebut.

Hasbi menyadari bahwa pendapatnya ini berseberangan dengan pendapat majelis ulama-ulama besar Saudi Arabia dalam keputusan No. 67, 21 Syawwal 1399 H / 1978 M. Keputusan itu berisi fatwa keharaman menulis (menafsirkan) Alquran dengan menggunakan selain bahasa Arab. Namun Hasbi tetap menyelesaikan tafsirnya menggunakan bahasa Indonesia. ${ }^{16}$ Sebagai konsekuensi logis pendapatnya, Hasbi kemudian menulis tafsir Alquran dengan menggunakan selain bahasa Arab, yaitu bahasa Indonesia. Apa yang dilakukan Hasbi juga dapat dilihat sebagai bentuk tanggung jawab intelektualnya.

Motivasi Hasbi menulis tafsir dalam bahasa Indonesia diungkapkannya sebagai berikut:

Bagi mereka jang pengetahuanja tentang bahasa Arab dan qaedah-qaedahnja mudah memilih salah satu tafsir jang mu'tabar, besar atau sederhana jang ditulis para ulama jang kebilangan di dalam bahasa Arab itu. Mereka dengan mudah memilih salah satu

\footnotetext{
${ }^{15}$ Nourouzzaman Shiddiqi, Fiqh Indonesia, h. 107.

${ }^{16}$ Nourouzzaman Shiddiqi, Fiqh Indonesia, h. 107.
} 
tafsir jang ditulis para sardjana secara ilmijah selaras dengan perkembangan zaman baru ini. Akan tetapi para peminat tafsir jang tidak mengetahui dengan dalam bahasa Arab, tentulah djalan memahamkan tafsir-tafsir dalam bahasa Arab itu tertutup baginja. Indonesia menghadjati tafsir dalam bahasa persatuan Indonesia. ${ }^{17}$

Demikian pendapat Hasbi tentang penulisan dan penerjemahan Alquran kedalam bahasa Indonesia. Bagi orangorang yang mengerti bahasa Arab beserta kaidah-kaidahnya, memahami Alquran dan maknanya yang berbahasa Arab mungkin tidak menjadi persoalan, namun bagi yang tidak memiliki kemampuan bahasa Arab, dapat dipastikan akan mengalami kesulitan dalam memahami Alquran tersebut. Dalam konteks inilah, Hasbi benar-benar berkeyakinan untuk menafsirkan Alquran menggunakan bahsa Indonesia. Adanya tafsir yang menggunakan bahasa Indonesia ini bertujuan untuk memberikan kemudahan bagi masyarakat yang kurang pemahamannya terhadap bahasa Arab untuk bisa memahami Alquran sehingga dapat mengamalkan isinya.

Selain itu, Hasbi melihat adanya perkembangan yang signifikan dalam sejumlah perguruan tinggi di Indonesia, yaitu munculnya upaya perhatian dan pelebaran kebudayaan Islam. Hal ini merupakan fenomena yang menggembirakan sehingga dalam pandangan Hasbi harus diimbangi dengan penafsiran Alquran, sunah Nabi dan kitab-kitab Islam klasik lainnya dengan menggunakan bahasa Indonesia.

Penulisan tafsir ini juga bertujuan untuk menambah khazanah keilmuan Islam dalam masyarakat Indonesia. Hasbi ingin menghasilkan suatu tafsir yang sederhana, ringkas, dan mampu menjadi sarana yang efektif untuk memahami Alquran

${ }^{17}$ Hasbi ash-Shiddieqy, Tafsir al-Qur'an al-Madjid an-Nur jilid I, (Semarang, Pustaka Rizki Putra, 2000), h. 4. 
sebagaimana eksistensi Alquran itu sendiri. Tujuan inilah yang mendorong semangat Hasbi dalam menyusun kitab tafsir ini. ${ }^{18}$

2. Identifikasi Kitab

Tafsir Alquran al-Madjid an-Nur yang selanjutnya penulis sebut dengan dengan Tafsir an-Nur merupakan karya monumental Hasbi, ia berhasil merampungkan seluruh isi Alquran yaitu 30 juz. Kadangkala tafsir an-Nur diterbitkan perjilid sejumlah juz Alquran. Setiap jilidnya mencapai kurang lebih 200 halaman. Kadangkala diterbitkan menjadi 10 jilid dimana perjilidnya masing-masing memuat 3 juz, dalam setiap jilid, biasanya berjumlah kurang lebih $3 \times 200$ halaman, yaitu 600 halaman. $^{19}$

Tafsir an-Nur terdiri dari 10 jilid dan setiap jilidnya memuat 3 juz:

1. Jilid I memuat juz 1 sampai juz 3, pertama kali dicetak pada tahun 1960, sedangkan cetakan keduanya pada tahun 1969.

2. Jilid II memuat juz 4 sampai juz 6, cetakan pertama di diterbitkan pada tahun 1961, cetakan kedua pada tahun 1964 dan cetakan ketiga pada tahun 1970.

3. Jilid III memuat juz 7 sampai juz 9, dicetak pertama kali pada tahun 1964.

4. Jilid IV memuat juz 10 sampai juz 12, dicetak pertama kali pada tahun 1964.

5. Jilid V memuat juz 13 sampai juz 15, dicetak pertama kali pada tahun 1969.

6. Jilid VI memuat juz 16 sampai juz 18 , dicetak pertama kali pada tahun 1964.

7. Jilid VII memuat juz 19 sampai juz 21, dicetak pertama kali pada tahun 1965 .

${ }^{18}$ Hasbi ash-Shiddieqy, Tafsir al-Qur'an, h. xi.

${ }^{19}$ Saiful Amin, "Studi Perbandingan Tafsir an-Nur dan Tafsir al-Bayan Karya Hasbi ash-Shiddieqy”, Skripsi Fakultas Ushuluddin UIN Sunan Kalijaga Yogyakarta, 2004, h. 30. 
8. Jilid VIII memuat juz 22 sampai juz 24, dicetak pertama kali pada tahun 1970 .

9. Jilid IX memuat juz 25 sampai juz 27, dicetak pertama kali pada tahun 1972 .

10. Jilid $X$ memuat juz 28 sampai juz 30, dicetak pertama kali pada tahun 1973. Tafsir an-Nur ini diterbitkan oleh penerbit Bulan Bintang di Jakarta.

Tafsir an-Nur ini selesai sebelum Hasbi wafat pada tanggal 19 Desember 1975. Bahkan setelah penerbitan cetakan pertama, Hasbi sempat meralat beberapa kekeliruan tulisan dan kesalahan cetak. Setelah sebagian juz ini beredar, Hasbi sempat mendapat sejumlah kritikan pedas mengenai orisinalitas karya tersebut, merespon kritikan tersebut Hasbi kemudian berkomentar: ${ }^{20}$

Menurut berita-berita yang sampai kepada saya, ada orang yang melihat/membaca sepintas lalu tafsir an-Nur ini disebut-sebut sebagai terjemahan $100 \%$ dari sesuatu tafsir berbahasa Arab yang ditulis oleh ulama mutaqaddimin atau ulama belakangan ini. Bahkan menurut suara-suara yang sampai kepada saya, tafsir ini adalah terjemahan dari tafsir al-Maraghi. Mungkin demikian ini dimaksudkan untuk mengurangi minat pembaca pada tafsir ini.

Tafsir ini disusun dengan berpedoman kepada sejumlah tafsir induk, yaitu kitab-kitab tafsir yang menjadi pegangan bagi penulispenulis tafsir, baik tafsir bi al-ma'tsur, kitab-kitab bi al-ma'qul ataupun kitab-kita tafsir yang menyarikan uraian tafsir induk, terutama 'Umdat al-Tafsir 'an al-Hafiz Ibn Kasir, tafsir al-Manar, tafsir al-Qasimy, tafsir al-Maraghi, tafsir al-Wadih. ${ }^{21}$

Kemudian di dalam menerjemahkan ayat kedalam bahasa Indonesia, Hasbi berpedoman kepada tafsir Abu Su'ud, tafsir Shiddiq Hassan Chan dan tafsir al-Qasimy, terjemahan lafadz

\footnotetext{
${ }^{20}$ Hasbi ash-Shiddieqy, Tafsir al-Qur'an, h. 9.

${ }^{21}$ Hasbi ash-Shiddieqy, Tafsir al-Qur'an h. 9.
} 
berdasarkan kepada ketiga tafsir tersebut. Berkaitan dengan materi tafsir, kebanyakan disari dari tafsir al-Maraghy yang mengikhtisarkan uraian tafsir al-Manar. Sedangkan ayat dan hadis yang dinukilkan dalam tafsir ini terdapat dalam tafsir-tafsir induk dan tafsir-tafsir yang mengambil dari tafsir induk tersebut, seperti al-Maraghy. Dalam menerangkan ayat-ayat yang semakna dengan ayat yang ditafsirkan, Hasbi berpedoman kepada tafsir Ibn Katsir karena tafsir tersebut adalah tafsir yang menafsirkan ayat dengan ayat. ${ }^{22}$ Penulisan tafsir an-Nur ini walaupun ditulis menggunakan bahasa Indonesia, namun bahasa penulisan yang digunakan masih menggunakan ejaan lama.

\section{Corak Tafsir}

Dalam kamus Indonesia-Arab corak diartikan dengan 'launun' (warna) dan 'syaklun' (bentuk). ${ }^{23}$ Namun sampai saat ini, belum ditemukan ulama tafsir yang menggunakan kata 'syaklun' untuk menunjukkan corak, sehingga tidak ada yang menyebutkan 'syaklun at-tafsir'. Sebaliknya, istilah 'launun' bentuk pluralnya 'alwan' dapat ditemukan dalam kitab Tafsir wa al-Mufassirun. ${ }^{24}$

Dari definisi diatas dapat diketahui bahwa corak penafsiran yang dimaksud disini adalah bidang keilmuan yang mewarnai suatu kitab tafsir. Hal ini disebabkan karena setiap mufasir memiliki latar belakang keilmuan yang berbeda-beda, sehingga tafsir yang dihasilkan pun memiliki corak sesuai dengan disiplin keilmuan yang dikuasainya. Ada beberapa macam corak penafsiran antara lain: ${ }^{25}$

\footnotetext{
1988), h. 173

${ }^{24}$ Al-Tafsir wa al-Mufassirun, I, h. 140. III, h. 162.

${ }^{25}$ Acep Hermawan, Ulumul Qur'an (Bandung: Remaja Rosdakarya,
}

${ }^{22}$ Hasbi ash-Shiddieqy, Tafsir al-Qur'an, h. 9.

${ }^{23}$ Rusyadi, dkk., Kamus Indonesia - Arab (Jakarta: Balai Pustaka, 2011), h. 115. 
408 Rausyan Fikr, Vol. 14 No. 2 Desember 2018: 395-426

1. Tafsir Shufi identik dengan tafsir al-isyari, yaitu sesuatu metode penafsiran Alquran yang lebih menitikberatkan kajiannya pada pada makna batin dan bersifat alegoris. Penafsir yang mengikuti kecenderungan ini biasanya berasal dari kaum sufi yang lebih mementingkan persoalan-persoalan moral batin dibandingkan masalah zahir dan nyata. Di antara tafsir yang mengikuti corak ini adalah Tafsir Alquran alKarim oleh al-Tusturi dan Haqa'iq al-Tafsir Karya alSalami. $^{26}$

2. Tafsir Fiqhi, yakni salah satu corak tafsir yang pembahasannya berorientasikan kepada persoalan-persoalan hukum Islam. Tafsir jenis ini banyak sekali terdapat dalam sejarah Islam terutama setelah madzhab fiqih berkembang pesat. Sebagian di antaranya memang disusun untuk membela suatu madzhab fiqh tertentu. Di antara kitab tafsir yang masuk ke dalam kategori ini adalah Ahkam Alquran oleh al-Jashash dan al-Jami' Li Ahkam Alquran karya Qurthubi. $^{27}$

3. Tafsir Falsafi, adalah tafsir yang di dalam penjelasannya menggunakan pendekatan filsafat, termasuk dalam hal ini adalah tafsir yang bercorak kajian ilmu kalam. Corak ini muncul karena adanya penerjemahan kitab-kitab filsafat yang mempengaruhi beberapa pihak serta masuknya penganut agama-agama lain ke dalam Islam yang pada akhirnya menimbulkan pendapat yang dikemukakan dalam tafsir mereka. Tafsir yang mengikuti corak ini tdak begitu banyak.

${ }^{26}$ M. Alfatih Suryadilaga (dkk), Metodologi Ilmu Tafsir (Yogyakarta: Teras, 2005), h. 44.

${ }^{27}$ M. Alfatih Suryadilaga (dkk), Metodologi, h. 44. 
Bahkan, bisa dikatakan tidak ada karya tafsir falsafi yang lengkap. ${ }^{28}$

4. Tafsir 'Ilmi, adalah tafsir yang lebih menekankan pembahasannya dengan pendekatan ilmu-ilmu pengetahuan umum. Kelebihan tafsir ini adalah memperlihatkan bahwa Alquran tidak bertentangan dengan imu pengetahuan. Bahkan secara sistematis mendorong pengembangan ilmu pengetahuan yang sangat dibutuhkan oleh umat manusia. Adanya tafsir model seperti ini akibat dari perkembangan ilmu pengetahuan dan tekhnologi. Maka muncul usaha-usaha penafsiran Alquran sejalan dengan perkembangan ilmu pengetahuan yang terjadi. Tafsir jenis ini berkembang pesat setelah kemajuan peradaban di dunia Islam. Meskipun demikian, jumlah kitab tafsir yang mengikuti metode ini tidaklah begitu banyak. Mafatih al-Ghoib karya al-Razi ada yang menggolongkannya ke dalam tafsir jenis ini. ${ }^{29}$

5. Tafsir al-Adab al-Ijtima'i, adalah salah satu corak penafsiran Alquran yang menekankan pembahasannya pada masalahmasalah sosial kemasyarakatan. Tafsir yang menitikbertkan penjelasan ayat-ayat Alquran pada segi ketelitian redaksinya yang bertujuan untuk membawa petunjuk dalam kehidupan. Kemudian mengadakan pengertian ayat tersebut dengan hukum-hukum alam yang berlaku dalam masyarakat dan pengembangan dunia. Tafsir jenis ini lebih banyak mengungkapkan hal-hal yang ada kaitannya dengan perkembangan kebudayaan yang sedang berlangsung. Tafsir al-manar karya muhammad abduh dan rasyid ridha, almaraghi dan muhammad syalthuth dengan tafsir Alquran al-

\footnotetext{
${ }^{28}$ M. Alfatih Suryadilaga (dkk), Metodologi, h. 45.

${ }^{29}$ M. Alfatih Suryadilaga (dkk), Metodologi, h. 45.
} 
adhim dapat digolongkan mengikuti corak al-adab al-ijtima'i ini. $^{30}$

Tafsir an-Nur sendiri banyak disarikan dari beberapa kitab tafsir sebelumnya, sesuai dengan pernyataan Hasbi yang telah disebutkan sebelumnya. Jika ditelusuri kembali jelas tafsir an-Nur karya Hasbi ini menampakkan warna tentang fiqh atau hukum Islam yang cukup jelas. Terbukti dengan luasnya penafsiran ayatayat yang berkaitan dengan hukum atau masalah-masalah fiqh. Hal tersebut dapat dipahami mengingat Hasbi sendiri berlatar belakang akademik Syariah.

Oleh karena itu, penulis berkesimpulan bahwa corak tafsir dalam tafsir an-Nur adalah corak tafsir fiqh. Namun demikian, walaupun tafsir ini didominasi dengan corak fiqh, namun hal tersebut tidak menafikan corak lainnya seperti corak Adab alIjtima'i. Karena seperti yang telah disebutkan Hasbi di dalam muqaddimah tafsirnya bahwa ia ingin menjadikan bahasa tafsir anNur ini mudah dipahami dan diterima oleh masyarakat. Sehingga semaksimal mungkin masyarakat dapat memahami isi kandungan Alquran.

\section{Sistematika Penafsiran}

Bagian pertama dari aspek teknik penulisan tafsir adalah sistematika penyajian tafsir. Sistematika penyajian tafsir yang dimaksud adalah rangkaian yang dipakai dalam penyajian tafsir. Sebuah karya tafsir secara teknis dapat disajikan dalam sistematika penyajian yang beragam.

Dalam kaitannya dalam penyusunan kitab tafsir perlu diketahui adanya tiga sistematika penyusunan tafsir yang dikenal di kalangan para ahli tafsir diantaranya: Pertama, tartib mushafi (urutan ayat dan surat), dalam sistematika ini mufassir menguraikan penafsirannya berdasarkan urutan ayat dan surat di

\footnotetext{
${ }^{30}$ M. Alfatih Suryadilaga (dkk), Metodologi, h. 151.
} 
dalam mushaf (usmani). Dimulai dari surat al-Fatihah, al-Baqarah, Ali Imran, an-Nisa', al-Ma'idah hingga seterusnya sampai surat anNas. ${ }^{31}$ Kedua, tartib nuzuli (urutan kronologi turunnya surat-surat), yaitu menafsirkan Alquran berdasarkan kronologis turunnya suratsurat Alquran. ${ }^{32}$ Ketiga, tartib maudhu'i (urutan sesuai tema), yaitu menafsirkan Alquran berdasarkan topik-topik tertentu dengan mengumpulkan ayat-ayat yang ada hubungannya dengan topik tertentu kemudian ditafsirkan. ${ }^{33}$

Islah gusmian membagi sisi sistematika penyajian kedalam dua kelompok:

Pertama, sistematika penyajian runtut. Merupakan model sistematika penyajian penulisan tafsir yang rangkaian penyajiannya mengacu pada:

1. Urutan surat yang ada dalam model mushaf standar. Model ini sudah umum dipakai oleh para mufassir. Contohnya seperti karya tafsir klasik seperti Jalalain, maupun karya tafsir kontemporer seperti al-Manar.

2. Mengacu pada urutan turunnya wahyu. Model kedua ini tidak banyak ditempuh oleh ulama tafsir. Adapun contoh tafsir yang menggunakan penyajian tafsir model ini antara lain: al-Tafsir al-Bayani li Alquran al-Karim karya bint alSyati' dan Surah al-Rahman wa Sumar Qisar karya Syawqi Dha'if.

Kedua, sistematika penyajian tematik, sistematika penyajian tematik yang dimaksud adalah suatu bentuk rangkaian penulisan

${ }^{31}$ Muhammad Yusuf, dkk., “Jami' al-Bayan fi Tafsir al-Qur'an Karya Ibnu Jarir al-Tabari” A. Rafiq (ed.,) Studi Kitab Tafsir Menyuarakan Teks Yang Bisu (Yogyakarta: Teras, 2004), h. 34.

${ }^{32}$ Muhammad Yusuf, dkk., 'al-Jami' li Ahkam al-Qur'an wal Mubayyin Lima Tadammanah min al-Sunnah wa Ayil Furqan Karya al-Qurtubi”, dalam Indal Abror, Studi Kitab Tafsir Menyuarakan Teks Yang Bisu (Yogyakarta: Teras, 2004), h. 68.

${ }^{33}$ Muhammad Yusuf, dkk., “al-Jami’ li Ahkam, h. 68. 
karya tafsir yang struktur paparannya diacukan pada tema tertentu atau pada ayat, surat, dan juz tertentu. Literatur tafsir yang menggunakan model penyajian tematik dapat dikelompokkan menjadi dua bagian pokok. Diantaranya:

1. Penyajian tematik klasik, model sistematika penyajian tafsir yang mengambil satu surat tertentu dengan topik sebagaimana tercantum dalam surat yang dikaji tersebut.

2. Penyajian tematik modern, model sistematika penyajian karya tafsir yang mengacu pada tema tertentu yang ditentukan sendiri oleh seorang mufassir.

Hasbi sendiri dalam menulis kitab tafsirnya telah menempuh sistematika yang pertama (tartib mushafi) atau sistematika penyajian runtut, yakni menafsirkan Alquran menurut susunan urutannya dalam mushaf, dalam artian model sistematika penyajian penulisan tafsir yang rangkaian penyajiannya mengacu pada urutan surat yang ada pada model mushaf standar. ${ }^{34}$

Dalam kaitan ini Hasbi telah merampungkan seluruh penafsiran Alquran, dimulai dari surat al-Fatihah dan diakhiri dengan surat an-Nisa'. Adapun sistematika sebagai langkah metodis yang ditempuh oleh Hasbi, biasanya disetiap awal surat dimulai dengan muqaddimah dengan menguraikan seluk beluk seputar surat yang akan ditafsirkan. Misalnya tentang jumlah ayat, makiyah atau madaniyah, kandungan pokok yang terdapat pada surat tersebut dan bagaimana hubungan (munasabah) dengan surat sebelumnya.

Model teknis penulisan yang diawali dengan bagian muqaddimah, dilanjutkan dengan uraian ayat di setiap surat dengan menyebutkan ayat-ayat Alquran dan langsung menjelaskan makna

${ }^{34}$ Sajida Putri, "Epistemologi Tafsir Hasbi ash-Shiddieqy Dalam Kitab Tafsir al-Qur'an al-Madjid an-Nur", Tesis Fakultas Pascasarjana UIN Sunan Kalijaga Yogyakarta, 2015, h. 77. 
kandungan ayat demi ayat. Kemudian dalam analisisnya terkadang juga ia menyebutkan asbab an-nuzul nya jika ada, kemudian mengutip riwayat hadis atau qaul sahabat atau tabi'in.

\section{METODE PENAFSIRAN}

Berkaitan dengan upaya menjaga penafsiran Alquran dari kekeliruan, maka upaya yang hendak dikaji adalah berkaitan dengan metode penafsiran yang dilakukan oleh mufasir dalam merespon gejala-gejala atau problematika dalam kehidupan. Metode merupakan bagian yang tidak dapat dipisahkan dari kajian tafsir, karena keberadaannya sangat penting di dalam penafsiran.

Seorang mufasir sebagaimana yang dikatakan oleh Nashruddin Baidan adalah seorang komunikator (juru bicara) bagi Alquran. Dan sebagai seorang komunikator yang baik, mufasir hendaknya berusaha sebaik mungkin dalam menafsirkan Alquran agar pesan tersebut mencapai sasaran (komunikan) secara tepat. Untuk itu, penguasaan metodologi tafsir secara baik merupakan hal yang sangat penting bagi komunikator. Sehingga tafsiran yang dihasilkan dari suatu ayat tidak melenceng, tujuan atau target tepat sasaran dan pesan yang terkandung dalam Alquran tersebut dapat dipahami dengan baik.

Kata metode sendiri berasal dari bahasa Yunani yaitu methods, yang berarti cara atau jalan. Dalam bahasa Inggris, kata ini ditulis method, sedangkan dalam bahasa Arab diterjemahkan dengan thariqat dan manhaj. Dalam bahasa Indonesia sendiri, kata tersebut mengandung arti cara yang teratur dan terpikir baik-baik untuk mencapai maksud (dalam ilmu pengetahuan dan sebagainya), cara kerja yang bersistem untuk memudahkan pelaksanaan suatu kegiatan guna mencapai suatu yang ditentukan. ${ }^{35}$

${ }^{35}$ Nashruddin Baidan, Metodologi Penafsiran al-Qur'an (Yogyakarta: Pustaka Pelajar, 2012), h. 1. 
414 |Rausyan Fikr, Vol. 14 No. 2 Desember 2018: 395-426

Adapun metodologi tafsir sendiri adalah ilmu tentang menafsirkan Alquran. Dengan demikian, dapat dibedakan antara dua istilah tersebut, yaitu: metode tafsir, cara menafsirkan Alquran; sementara metodologi tafsir, ilmu tentang cara tersebut. ${ }^{36}$ Jadi, metode tafsir merupakan kerangka atau kaidah yang digunakan dalam menafsirkan ayat-ayat Alquran. Sedangkan metodologi tafsir adalah pembahasan ilmiah tentang metodemetode penafsiran Alquran.

Metode yang digunakan oleh para mufasir kontemporer pada umumnya berbeda dengan metode yang biasa digunakan oleh para mufasir tradisional. Jika para mufasir tradisionalis cenderung menggunakan metode analitis (tahlili), maka para mufasir kontemporer lebih menggunakan berbagai metode dan pendekatan yang bersifat disipliner. ${ }^{37}$

Dalam menafsirkan Alquran, ada empat metode yang dikembangkan oleh para ulama, yaitu metode global (ijmali), metode analitis (tahlili), metode perbandingan (muqaran), dan metode tematik (maudhu'i). ${ }^{38}$ Dan keempat metode tersebut mempunyai ciri dan spesifikasi masing-masing.

Metode tahlili adalah metode tafsir yang bermaksud menjelaskan kandungan ayat Alquran dari seluruh aspeknya. Dalam menafsirkan Alquran, mufasir mengikuti runtutan ayat sebagaimana yang telah tertera di dalam Alquran. Pertama, dengan mengemukakan arti kosakata kemudian diikuti dengan penjelasan makna secara global. Mufasir juga mengungkapkan munasabah (hubungan/korelasi) antar ayat dan menjelaskan maksud hubungan antara ayat tersebut. Menyebutkan asbab an-nuzul dan dalil-dalil dari rasul, para sahabat, tabi'in, serta para ulama dan

${ }^{36}$ Nashruddin Baidan, Metodologi Penafsiran al-Qur'an ...., h. 2.

${ }^{37}$ Abdul Mustaqim, Epistimologi Tafsir Kontemporer..., h. 68.

${ }^{38}$ Nashruddin Baidan, Wawasan Baru Ilmu Tafsir (Yogyakarta: Pustaka Pelajar, 2011), h. 380. 
dikombinasikan dengan pendapat para mufasir itu sendiri serta diwarnai dengan ilmu yang digelutinya. ${ }^{39}$ Contoh tafsir yang menggunakan metode ini diantaranya adalah Mafatih al-Ghaib karya al-Razi, Jami' al-Bayan fi Tafsir Alquran al-'Azhim karya Ibnu Jarir at-Tabari, Ma'alim al-Tanzil karya Ibnu Kasir dan lain sebagainya.

Metode ijmali adalah suatu metode tafsir yang menafsirkan Alquran dengan cara mengemukakan makna global. ${ }^{40}$ Metode global (ijmali) dan analitis (tahlili) pada dasarnya mempunyai bentuk yang sama, terutama dari sudut penalaran dan proses berfikir. Hanya saja, perbedaannya terletak pada wacana. Pada metode global wacananya amat sedikit dan ruang lingkupnya amat sempit, sebaliknya metode analitis wacananya sangat banyak dan mempunyai ruang lingkup yang sangat luas. Contoh tafsir yang menggunakan metode ini antara lain Tafsir Alquran al-Karim karya Muhammad Farid al-Wajdi dan Tafsir al-Wasit terbitan Majma' alBuhus al-Islamiyyah. ${ }^{41}$

Metode muqaran (metode komparatif/perbandingan), metode tafsir ini adalah dengan mengemukakan penafsiran ayat Alquran yang pernah ditulis oleh beberapa mufasir sebelumnya. Dalam hal ini mufasir menghimpun ayat-ayat Alquran yang akan diteliti

${ }^{39}$ Abu Hayy al-Farmawi, Metode Tafsir Maudhi'i Suatu Pengantar terj. Suryan A. Jamrah (Jakarta: Raja Gravindo Persada, 1994), h. 11. Definisi lain mengatakan bahwa metode tahlili adalah tafsir yang menyoroti ayat-ayat alQur'an dengan memaparkan segala makna dan aspek yang terkandung di dalamnya sesuai urutan bacaan yang terdapat di dalam Mushaf Usmani. Dibandingkan dengan metode tafsir lainnya, metode tahlili adalah metode yang paling tua. Tafsir ini ada sejak para sahabat nabi. Lihat, quraish shihab dkk., sejarah dan 'ulum al-qur'an dalam azzumardi azra (ed.,) (jakarta: pustaka firdaus, 2001), h. 172.

${ }^{40}$ Abu Hayy al-Farmawi, Metode Tafsir Maudhu'i Suatu Pengantar, terj. Suryan A. Jamrah (Jakarta: Raja Gravindo Persada, 1994), h. 13.

${ }^{41}$ Abu Hayy al-Farmawi, Metode Tafsir Maudhu'i Suatu Pengantar, terj. Suryan A. Jamrah (Jakarta: Raja Gravindo Persada, 1994), h. 13. 
kemudian meneliti tafsiran ayat-ayat tersebut dengan merujuk kepada tafsir utama yang akan dibandingkan tersebut. ${ }^{42}$

Metode maudhu'i atau tematik adalah memahami ayat-ayat Alquran dengan cara memfokuskan pada topik atau tema tertentu yang akan dikaji. Al-Farmawi merupakan orang pertama yang merumuskan secara sistematis mengenai langkah-langkah metode ini. $^{43}$

Dari keempat metode tersebut dapat diketahui bahwa metode yang ditempuh oleh Hasbi dalam menafsirkan Alquran dapat dikategorikan sebagai metode global (ijmali). Kategori ini dikarenakan Hasbi menafsirkan ayat secara global. Terlihat ketika Hasbi menafsirkan ayat-ayat Alquran tidak menjelaskan secara rinci. Pola-pola penjelasannya juga singkat, sederhana dan hanya mengungkapkan kandungan makna suatu ayat secara umum. Meski demikian, menurut pendapat penulis metode yang digunakan tidak murni ijmali. Tafsir an-Nur juga menggunakan metode analitis (tahlili). Ada penggabungan antara ijmali dan tahlili dalam menafsirkan ayat-ayat Alquran. Dikatakan menggunakan metode tahlili karena Hasbi juga menggunakan ayat-ayat tertentu secara luas. Terkadang dalam menafsirkan ayat Hasbi mengungkapkan munasabah (hubungan/korelasi) antar ayat dan menjelaskan maksud hubungan antara ayat tersebut.

Kemudian juga menyebutkan asbab an-nuzul dan dalil-dalil dari rasul, para sahabat, tabi'in, serta para ulama dan dikombinasikan dengan pendapatnya sendiri serta diwarnai dengan ilmu yang digelutinya. Metode seperti ini merupakan ciri-ciri dari metode tahlili. Asumsi penulis, metode yang dilakukan Hasbi dipengaruhi oleh Ibnu Kasir yang juga menggabungkan dua

${ }^{42}$ Abu Hayy al-Farmawi, Metode Tafsir Maudhu'i Suatu Pengantar, terj. Suryan A. Jamrah (Jakarta: Raja Gravindo Persada, 1994), h. 30.

${ }^{43}$ Abdul Mustaqim, Epistimologi Tafsir Kontemporer..., h. 68. 
metode. ${ }^{44}$ Hal ini dikatakan karena dalam menulis tafsir ini Hasbi juga banyak merujuk kepada kitab tafsir ini.

Berikut ini contoh bagaimana Hasbi menafsirkan ayat Alquran dengan menggunakan metode ijmali:

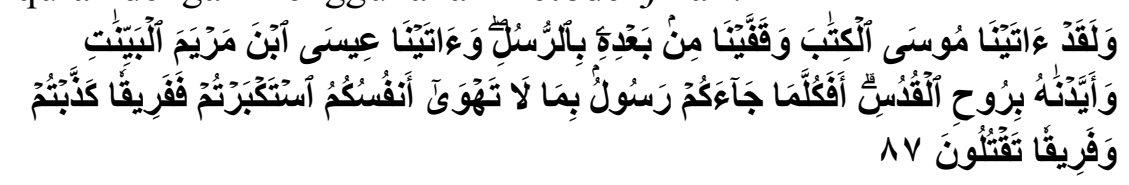

'Dan sesungguhnya kami telah mendatangkan al-kitab (taurat) kepada musa, dan kami telah menyusulinya (berturut-turut) sesudah itu dengan rasul-rasul, dan telah kami berikan bukti-bukti kebenaran (mukjizat) kepada isa putera maryam dan kami memperkuatnya dengan ruhul qudus. Apakah setiap datang kepadamu seorang rasul membawa sesuatu (pelajaran) yang tidak sesuai dengan keinginanmu lalu kamu menyombong; maka beberapa orang (diantara mereka) kamu dustakan dan beberapa orang (yang lain) kamu bunuh?" (Q.S. al-baqarah: 87)

Tafsirannya: ${ }^{45}$

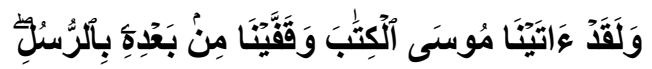

'Dan sesungguhnya kami telah mendatangkan al-kitab (taurat) kepada musa, dan kami telah menyusulinya (berturut-turut) sesudah itu dengan rasul-rasul."

${ }^{44}$ Penggabungan dua metode seperti ini dapat dilihat dalam kitab Tafsir al-Qur'an al-'Azhim/Tafsir ibn Kasir. Dalam tafsirnya tersebut, metode yang ditempuh Ibnu Kasir dalam menafsirkan al-Qur'an dapat dikategorikan sebagai metode tahlili. Kategori ini dikarenakan pengarangnya menafsirkan ayat demi ayat secara analitis menurut urutan Mushaf al-Qur'an. Namun demikian, metode penafsiran kitab tafsir ini juga dikatakan semi tematik (maudhu'i) karena ketika menafsirkan ayat Ibnu Kasir mengelompokkan ayat-ayat yang masih dalam satu konteks pembicaraan ke dalam satu tempat. Baik satu atau beberapa ayat. Kemudian menampilkan ayat-ayat lainnya yang terkait untuk menjelaskan ayat yang sedang ditafsirkan. Cara seperti ini sebelumnya juga telah ditempuh oleh alQurtubi (w. 671 H) dalam al-Jami' lil Ahkam al-Qur'an. Lihat Dedi Nurhaedi, "Tafsir al-Qur'an al- 'Azhim Karya Ibnu Kasir” dalam A. Rafiq (ed) Studi Kitab Tafsir (Yogyakarta: Teras, 2004), h. 138.

${ }^{45}$ Hasbi ash-Shiddieqy, Tafsir an-Nur Jilid I, h. 216. 
418 Rausyan Fikr, Vol. 14 No. 2 Desember 2018: 395-426

Yakni: Sungguh telah kami berikan kepada Musa sebuah kitab suci Taurat. Kemudian sesudah Musa itu kami kirimkan lagi Rasul demi Rasul menurut jejaknya.

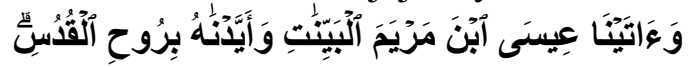

"Dan telah kami berikan bukti-bukti kebenaran (mukjizat) kepada isa putera maryam dan kami memperkuatnya dengan ruhul qudus."

Yakni: Allah memberikan kepada Isa berbagai mukjizat yang menunjuk kepada kebenaran kenabiannya. Dan Allah memperkuat Isa dengan ruh wahyu sebagaimana halnya dengan nabi yang lain. Dan inilah yang disebut dengan 'ruh suci'.

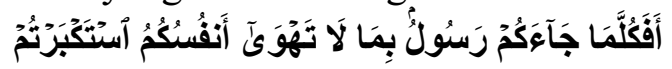

“Apakah setiap datang kepadamu seorang rasul membawa sesuatu (pelajaran) yang tidak sesuai dengan keinginanmu lalu kamu menyombong".

Yakni: apakah setiap datang kepadamu seseorang rasul dan rasul-rasul Allah membawa membawa agama yang tidak sesuai dengan nafsu-nafsumu maka kamu menyombongkan diri dan tidak mau mengimaninya.

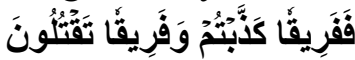

"Maka beberapa orang (diantara mereka) kamu dustakan dan beberapa orang (yang lain) kamu bunuh?"

Yakni: Bani Israil mendustakan sebagian rasul Isa dan seruan Muhammad dan membunuh sebagiannya seperti Zakaria dan Yahya.

Dari contoh tafsiran di atas terlihat bahwa Hasbi menafsirkan ayat tersebut dengan metode ijmali, ayat tersebut ditafsirkan secara global. Hasbi menyajikan beberapa penggalan ayat yang kemudian diterjemahkan kedalam bahasa Indonesia dan diikuti dengan penjelasan-penjelasan ayat secara ringkas. Asumsi penulis, penulisan ayat dengan literatur bahasa Indonesia ini dilakukan Hasbi karena ia beranggapan bahwa masih banyak pembaca yang 
masih belum memahami bahasa Arab, sehingga penulisan seperti ini dapat memudahkan pembaca dalam memahami tafsir tersebut.

Berbeda ketika Hasbi menafsirkan ayat-ayat yang berkaitan dengan persoalan fiqh. Sebagai seorang yang ahli di bidang fiqh dan hukum Islam, ketika menafsirkan ayat-ayat yang bernuansa hukum, Hasbi memberikan penjelasan yang relatif luas. Seperti ketika Hasbi menafsirkan ayat puasa dalam al-Baqarah: 183. Hasbi menjelaskan ayat ini dengan rinci, sehingga menghabiskan tiga halaman, persoalan puasa dikupas tuntas dengan menjelaskan manfaat puasa tersebut. Kemudian memasukkan ayat yang semakna serta pendapat para sahabat dan para ulama terdahulu.

Menurut asumsi penulis, penggunaan metode tahlili yang digunakan Hasbi ini didasari dua alasan: pertama, Hasbi adalah mufasir yang banyak merujuk dan mengambil sumber dari kitabkitab tafsir lama, yang banyak menggunakan metode tahlili. Kedua, Hasbi menafsirkan Alquran tergantung kebutuhan. Ketika ia menafsirkan ayat-ayat fiqh/hukum yang membutuhkan penjelasan lebih rinci, ia akan menggunakan metode tahlili dalam menafsirkan.

Penafsiran lebih detail terhadap ayat-ayat yang bercorak fiqh atau hukum ini, asumsi penulis karena Hasbi seorang mufasir yang berlatar belakang akademik hukum dan sebagai pembaharu fiqh di Indonesia. Sehingga ayat-ayat yang berkaitan dengan fiqh lebih ditonjolkan penafsirannya.

Munculnya berbagai kitab tafsir tidak dapat dipisahkan dari perbedaan metode penafsiran Alquran. Metode disini diartikan dengan cara kerja mufasir yang dilakukan dengan cara sistematis. Ada berbagai metode yang dipakai mufasir didalam menafsirkan Alquran dan ini erat sekali dengan sumber apa yang mereka pergunakan. Ada tafsir Alquran yang penafsirannya didasarkan atas sumber Alquran, hadis, riwayat sahabat, dan tabi'in yang kemudian 
dikenal dengan metode bi al-ma'sur. ${ }^{46}$ Dan ada pula tafsir yang penafsirannya didasarkan atas sumber ijtihad, berdasarkan pendapat ulama-ulama dan berbagai teori pengetahuan. Penafsiran ini dikenal dengan metode bi al-ra'yi. ${ }^{47}$ Kemudian penafsiran Alquran dengan mengesampingkan (makna) lahiriah karena ada isyarat (indikator) tersembunyi yang hanya bisa disimak oleh orang-orang yang memiliki ilmu suluk dan tasawuf, penafsiran ini dikenal dengan tafsir isyarah. ${ }^{48}$

Selain bentuk-bentuk metode penafsiran sebagaimana diatas, ada juga kecenderungan mufasir untuk memadukan antara dua metode yaitu dengan mencari sumber penafsiran dari Alquran, hadis maupun dari sahabat dan tabi'in. Jika semua sumber itu tidak ada atau mungkin untuk memperjelas dalam penafsirannya maka kemudian didasarkan pada sumber ijtihad.

Penggunaan metode tafsir yang terakhir ini biasa dipakai oleh mufasir-mufasir abad modern yang ditulis sesudah kebangkitan kembali umat Islam. Metode semacam ini di Indonesia dapat dilihat dalam tafsir al-Azhar karya Hamka. Hamka sendiri menyatakan bahwa: ${ }^{49}$

${ }^{46}$ Nashruddin Baidan, Metode Penafsiran al-Qur'an (Yogyakarta: Pustaka Pelajar, 2002), h. 40.

${ }^{47}$ Nashruddin Baidan, Metode Penafsiran al-Qur'an (Yogyakarta: Pustaka Pelajar, 2002), h. 40.

${ }^{48}$ Ahmad Izzan, Metodologi Ilmu Tafsir (Bandung: Tafakur, 2007), h. 88. Sedangkan Manna' al-Qaththan menjelaskan tafsir isyari sebagai spiritual yang dilakukan seorang sufi untuk dirinya akan mengantarkan kepada suatu tingkatan dimana ia dapat menyingkap isyarat-isyarat qudus yang terdapat di balik ungkapan-ungkapan al-Qur'an. Artinya setiap ayat mempunyai makna lahir dan makna batin. Yang lahir adalah yang mudah dipahami akal pikiran, dan yang batin adalah isyarat-isyarat tersembunyi dibalik ayat yang tentunya hanya bisa dilihat oleh suluk. Manna' al-Qaththan, Pengantar Studi Ilmu al-Qur'an, terj. Ainur Rafiq el-Mazni (Jakarta: Pustaka al-Kautsar, 2007), h. 447.

${ }^{49}$ Samrotul Azizah, "Tafsir Tematik Ayat-Ayat Kalam Dalam Tafsir anNur", Skripsi Fakultas Ushuluddin Institut Agama Islam Negeri Walisongo Semarang, 2009, h. 52. 
"Penafsir hendaknya menjaga sebaik-baiknya antara naql dan akal, antara riwayah dan dirayah. Penafsir tidak hanya semata-mata mengutip pendapat orang yang terdahulu, tetapi mempergunkan juga tinjauan dan pengalaman.'

Merujuk kepada definisi Islah Gusmian bahwa di wilayah penafsiran, meskipun seorang mufasir menggunakan data-data bersumber pada riwayat, tetapi jika proses penafsirannya lebih pada usaha usaha rasionalisasi kontekstual riwayat itu, hal ini masih tergolong tafsir bi al-ra'yi, bukan bi al-ma'sur. ${ }^{50}$ Pada tafsir bi al-ra'yi, riwayat hanya difungsikan sebagai legitimasi untuk mendukung penafsiran yang diberikan, dan pemikiran mufasir terasa amat dominan. ${ }^{51}$

Menurut hemat penulis, walaupun Islah Gusmian mendefinisikan tafsir bi al-ra'yi seperti tersebut diatas, penulis berkesimpulan bahwa, tafsir an-Nur ini menggunakan campuran antara bi al-ra'yi dan bi al-ma'sur. Hal ini dapat dilihat dari sumber-sumber penafsiran yang telah dijelaskan sebelumnya bahwa sumber tafsir Hasbi adalah sumber al-naqli dan al-aqli. Hasbi berpedoman kepada riwayat yang shahih dan pertimbangan penalaran yang sehat. Hal ini dikarenakan Hasbi menyebutkan riwayat dalam tafsir an-Nur ini tidak hanya di dalam beberapa surat saja, tetapi hampir penafsirannya didominasi dengan hadishadis. Telah disebutkan pada penjelasan sebelumnya bahwa hadis hadis yang terdapat di dalam tafsir ini sebanyak 209 hadis. Dan ini juga berdasarkan pernyataan Hasbi di muqaddimah kitabnya yang mengatakan bahwa, dalam tafsir ini ia berpedoman kepada tafsir

${ }^{50}$ Lihat keterangan Islah Gusmian, Khazanah Tafsir Indonesia..., h. 213.

${ }^{51}$ Pada dasarnya baik tafsir bi al-ra' yi, tidak pernah mengenyampingkan riwayat. Riwayat bagi kedua bentuk penafsiran itu tetap diperlukan, hanya saja fungsinya berbeda. Lihat Nashruddin Baidan, Metodologi Penafsiran al-Qur'an..., h. 50-51. 
induk, baik itu kitab tafsir bi al-ma'sur maupun kitab tafsir bi alma'qul. $^{52}$

Tafsir an-Nur ini disusun dengan pembahasan yang diharapkan mampu menggugah minat pembaca sekaligus memudahkannya dalam memahami dan mendapat penjelasan yang relatif lengkap. Adapun langkah-langkah kongkrit metodologis tafsir an-Nur sebagai berikut:

1. Menjelaskan surat yang bersangkutan mulai dari nama surat, jumlah ayat, makkiyah atau madaniyyah, kandungan pokok yang terdapat dalam surat tersebut dan bagaimana hubungan (munasabah) dengan surat sebelumnya dalam memulai penafsiran suatu surat baru.

2. Penyajian tentang kandungan Alquran, dengan menyajikan bagian-bagian pendek yang terdiri dari beberapa ayat, satu sampai lima ayat, dengan terjemahan bahasa Indonesia bersamaan dengan teks Arabnya.

3. Menerjemahkan makna ayat dalam bahasa Indonesia agar mudah dipahami dengan memperhatikan makna-makna yang terkandung dalam masing-masing lafadz tersebut.

4. Menafsirkan ayat-ayat dengan menunjuk intisarinya secara global. Namun di bagian surat tertentu penafsiran ayat dilakukan secara terperinci.

5. Melakukan penafsiran ayat dengan ayat (munasabah) sebagai aplikasi norma tamatis (Alquran yufassiru ba'duhu ba'd), dengan menerangkan ayat-ayat yang semakna dengan ayat yang tengah ditafsirkan, sehingga memudahkan pembaca dalam mengumpulkan ayat-ayat.

6. Menafsirkan Alquran dengan hadis/sunah, memperkaya penjelasannya dengan mengutip sebuah riwayat atau

\footnotetext{
${ }^{52}$ Hasbi ash-Shiddieqy, Tafsir an-Nur jilid 1, h. 5.
} 
M. Abdurrahman Wahid, Corak dan Metodologi Tafsir ...

mengemukakan hadis yang berkaitan dengan ayat bersangkutan.

7. Mencantumkan pendapat ulama untuk menjelaskan hukumhukum yang berkaitan dengan pokok pembahasan.

8. Menerangkan sebab-sebab turun (asbab an-nuzul) ayat jika ditemukan riwayat yang shahih, dan diakui shahihnya oleh ahli-ahli asar. $^{53}$

9. Kemudian di akhir penafsiran, mengemukakan kesimpulan dari ayat yang sedang dibahas.

Penulis melihat ada kasus penafsiran Hasbi yang tidak konsisten, meski dalam banyak hal ia relatif konsisten dengan metodologi yang ditetapkannya. Adanya inkonsistensi Hasbi ini terlihat ketika ia menafsirkan ayat-ayat yang bercorak fiqh/hukum. Inkonsistensi tersebut dikarenakan tidak ada kesesuaian antara pernyataanya dengan metode tafsir yang digunakan. Di dalam muqaddimah tafsir an-Nur Hasbi menjelaskan bahwa: ${ }^{54}$

"Meninggalkan uraian yang tidak langsung berhubungan dengan tafsir ayat, supaya tidak selalu para pembaca dibawa keluar dari bidang tafsir baik ke bidang sejarah ataupun ke bidang ilmiyah yang lain."

Dengan ungkapan tersebut, Hasbi bermaksud untuk tidak menafsirkan ayat-ayat Alquran dengan uraian yang meliputi segala bidang tanpa memberi penekanan pada bidang tertentu. Hal ini berlawanan dengan penafsirannya di dalam tafsir an-Nur, ketika menafsirkan ayat-ayat tertentu, yang dalam hal ini ayat-ayat yang bercorak fiqh atau hukum Islam Hasbi menjelaskannya dengan sangat terperinci. Berbeda ketika ia menafsirkan ayat-ayat pada umumnya. Hal ini diduga karena Hasbi memiliki latar belakang

\footnotetext{
${ }^{53}$ Hasbi ash-Shiddieqy, Tafsir an-Nur juz 1..., h. 5.

${ }^{54}$ Hasbi ash-Shiddieqy, Tafsir an-Nur jilid 1, h. 3.
} 
keilmuan hukum Islam. Itu sebabnya mengapa fiqh atau hukum Islam lebih bercorak di dalam kitab tafsir an-Nurini.

\section{PENUTUP}

Hasbi ash-Shiddieqy adalah tokoh yang memiliki metode dan coraknya sendiri dalam menafsirkan Alquran, ia berupaya untuk melengkapi kebutuhan umat sesuai dengan zamannya. Metode yang digunakan dalam tafsirnya adalah metode tahlili (analitis) dan muqaran (komparatif), sedangkan corak tafsirnya adalah tafsir aladabi wa al-ijtima'iy. Tafsir Alquran al-Madjid an-Nur ini merupakan salah satu karya besar yang berpengaruh di Indonesia, hal ini dapat dilihat bahwa kitab tafsir ini menjadi rujukan PTAIN di Indonesia, baik di Fakultas Ushuluddin maupun di Fakultas Syari'ah.

Karya ini juga dapat dikatakan mampu memberikan khazanah intelektual muslim yang masih harus dipahami dan dikembangkan sesuai dengan situasi ruang dan waktu yang berubah setiap saat. Oleh karena itu, secara keilmuan, karya Hasbi ini tetap merupakan produk zaman dan masih harus melihat kesempurnaankesempurnaan lain pada zaman berikutnya. Ukuran-ukuran kemajuan akan segera tercapai manakala sebuah karya dianggap sebagai sebuah proses sejarah yang senantiasa mengalami transisi pada kurun temuan ahli berikutnya.

\section{DAFTAR PUSTAKA}

Abidin, Munirul. Paradigma Tafsir Perempuan di Indonesia. Malang: UIN Maliki Press, 2011.

Amin, Saiful. "Studi Perbandingan Tafsir an-Nur dan Tafsir alBayan Karya Hasbi ash-Shiddieqy". Skripsi Fakultas Ushuluddin UIN Sunan Kalijaga Yogyakarta, 2004.

Baidan, Nashruddin. Metodologi Penafsiran Alquran. Yogyakarta: Pustaka Pelajar, 2012. 
M. Abdurrahman Wahid, Corak dan Metodologi Tafsir ...

Baidan, Nashruddin. Wawasan Baru Ilmu Tafsir. Yogyakarta: Pustaka Pelajar, 2011.

Farmawi, Abu Hayy. Metode Tafsir Maudhu'i Suatu Pengantar, terj. Suryan A. Jamrah. Jakarta: Raja Gravindo Persada, 1994.

Ghofur, Saiful Amin. Profil Para Mufasir Alquran. Yogyakarta: Pustaka Insan Madani, 2008.

Gusmian, Islah. Khazanah Tafsir Indonesia. Yogyakarta: LkiS, 2013 .

Hermawan, Acep. Ulumul Qur'an. Bandung: Remaja Rosdakarya, 2011.

Izzan, Ahmad. Metodologi Ilmu Tafsir. Bandung: Tafakur, 2007.

Mustaqim, Abdul. Epistimologi Tafsir Kontemporer. Yogyakarta: LKiS, 2012.

Nurhaedi, Dedi. "Tafsir Alquran al-"Azhim Karya Ibnu Kasir" dalam A. Rafiq (ed) Studi Kitab Tafsir. Yogyakarta: Teras, 2004.

Putri, Sajida. "Epistemologi Tafsir Hasbi ash-Shiddieqy Dalam Kitab Tafsir Alquran al-Madjid an-Nur". Tesis Fakultas Pascasarjana UIN Sunan Kalijaga Yogyakarta, 2015.

Qaththan, Manna'. Pengantar Studi Ilmu Alquran, terj. Ainur Rafiq el-Mazni. Jakarta: Pustaka al-Kautsar, 2007.

Rusyadi. (dkk). Kamus Indonesia - Arab. Jakarta: Balai Pustaka, 1988.

Shiddieqy, Hasbi. Tafsir Alquran al-Madjid an-Nur jilid I. Semarang: Pustaka Rizki Putra, 2000.

Shiddiqi, Nourouzzaman. Fiqh Indonesia : Penggagas dan Gagasannya. Yogyakarta: Pustaka Pelajar, 1997.

Suryadilaga M. Alfatih. (dkk). Metodologi Ilmu Tafsir. A. Rafiq (ed.), Yogyakarta: Teras, 2005. 
426 |Rausyan Fikr, Vol. 14 No. 2 Desember 2018: 395-426

Yusuf, Muhammad. (dkk). “Jami' al-Bayan fi Tafsir Alquran Karya Ibnu Jarir al-Tabari” A. Rafiq (ed.,) Studi Kitab Tafsir Menyuarakan Teks Yang Bisu. Yogyakarta: Teras, 2004. 